\title{
O współczesnej kulturze popularnej na Słowacji
}

\author{
Agnieszka Janiec-Nyitrai (Budapešt)
}

Štefan Timko: Zábavné populárne žánre na Slovensku. Nitra: Univerzita Konštantína Filozofa v Nitre, Fakulta stredoeurópskych štúdií, 2015. 124 s. ISBN 978-80-558-0857-4.

Publikacja Zábavné populárne žánre na Slovensku autorstwa nitrzańskiego badacza i nauczyciela akademickiego Štefana Timki przeznaczona jest, jak sam autor podkreśla we wstępie, przede wszystkim dla studentów, ma więc formę skryptu. Stanowi wolną kontynuację monografii Situačná komédia a jej regionálne modely (Nitra, 2012), wydanej przez Timkę przed pięcioma laty. Publikacja przeznaczona jest $\mathrm{w}$ pierwszym rzędzie dla studentów kulturologii, estetyki, medioznawstwa, dziennikarstwa, socjologii, ale zainteresuje również tych, którzy chcą śledzić najnowsze zmiany we współczesnym dyskursie medialo-kulturalnym na Słowacji. Celem publikacji jest analiza szeroko pojętych gatunków rozrywkowych, jak sitcom czy seriale telewizyjne, ale także filmy fabularne dla szerokiej publiczności.) Timko analizuje te gatunki na przykładzie słowackiej kultury popularnej.

Podręcznik składa się z pięciu komplementarnych rozdziałów, w których autor postanawia przybliżyć aktualne problemy współczesnej słowackiej kultury, wykorzystując najnowsze teorie medialnej komunikacji, teorie $\mathrm{z}$ zakresu nauk społecznych, estetyki, ale także narratologii czy semiotyki. W pierwszym rozdziale poświęconym powstaniu i specyfice słowackiej kultury popularnej Timko rekapituluje definicje kultury popularnej, przybliża powstanie prasy bulwarowej oraz początki słowackiej kinematografii. Na konkretnym przykładzie fenomenu mitu Janosika w słowackiej tradycji i kulturze popularnej autor demonstruje, w jaki sposób do kultury (popularnej) przenikają elementy kultury ludowej. Szczegółowo analizuje film Jánošik (1935) w reżyserii Martina Friča, a następnie przestawia zarys historii słowackiej kinematografii po II wojnie światowej, poświęcając jednocześnie więcej miej- sca słowackiej kulturze popularnej rozwijającej się po roku 1945. Drugi rozdział noszący nazwę Humor a jeho špecifiká v slovenskej l’udovej i mediálnej kultúre przynosi refleksję ogólnego charakteru dotyczaca komiki i humoru. Bazując na szerokiej podbudowie teoretycznej autor przypomina podstawowe teorie komiki, ale również poświęca wiele miejsca specyficznym cechom słowackiego humoru. Ważny element tego rozdziału tworzy podrozdział dotyczacy rozwoju komedii w słowackiej kinematografii, ale także w słowackiej sztuce radiowej. W trzeciej części publikacji autor koncentruje się na rozwoju gatunków rozrywkowych w słowackiej telewizji ze szczególnym uwzględnieniem komedii sytuacyjnej - sitcomu. Przedostatni rozdział został poświęcony fenomenowi występowania subkultur młodzieżowych w serialach komediowych, a w ostatnim rozdziale publikacji Timko podkreśla istotność Internetu jako medium o dużym potencjalne rozrywkowym, szczególnie wyraźnego w kontekście rozwoju i ewoluowania gatunku serialu internetowego.

Jak wynika $\mathrm{z}$ tego pobieżnego przeglądu zawartości podręcznika tematyka poruszana przez autora jest szeroko zakrojona i różnorodna, niemiej jednak autorowi udało się uniknąć chaotycznego i wybiórczego potraktowania wybranej przez niego tematyki. Autor porusza poszczególne tematy w sposób świadomy i wyważony, kreśląc obraz współczesnego słowackiego świata rozrywki i uwzględniając najnowsze trendy, mody i zmiany w tak efemerycznym przecież świecie współczesnych mediów. Timko jest absolwentem kierunku scenariopisarstwo i dramaturgia w Bratysławie, co jest wyraźnie widoczne w jego publikacji. Widać, iż doskonale orientuje się we współczesnej sytuacji mediów na Słowa- 
cji, a jednocześnie posiada wiedzę teoretyczną z dziedziny teorii mediów i sztuk wizualnych. Publikacja Zábavné populárne žánre na Slovensku, pomimo iż jest przeznaczona głównie dla studentów, zawiera nie tylko podstawowe informacje, które pomoga młodym ludziom orientować się w skomplikowanym świecie współczesnych mediów, ale również może okazać się wartościowa dla wszystkich, którzy poszukują klarownego i logicznie podanego kompendium wiedzy o najnowszych zjawiskach związanych $\mathrm{z}$ rozwojem internetu, mediów wizualnych i mediów drukowanych.

Timko w jasny i przystępny sposób rekapituluje dotychczasowe badania poświęcone różnym gatunkom rozrywkowym w słowackim kontekście, jednocześnie jednak informacje te poszerza i uzupełnia. Tym samym skrypt Timki, który autor we wstępnie określił jako pod- ręcznik dla studentów, staje się jednocześnie oryginalną i wartą uwagi publikacją naukowego charakteru. Poszczególne rozdziały można by oczywiście dopełnić, pogłębiając je jednocześnie merytorycznie, np. podczas analizy fenomenu Janosika w słowackiej kulturze warto oprzeć się o ważną monografię polskiej slawistki Joanny Goszczyńskiej (Mýtus o Jánošikovi vo folklóre a slovenskej literatúre 19. storočia. Bratislava, 2003), ale w opublikowanej formie stanowi dobra pomoc dla studentów kierunków humanistycznych. Publikację można uznać za doskonały punkt wyjścia dla tych, którzy chca poznać niełatwy świat współczesnej kultury popularnej na Słowacji ze szczególnym uwzględnieniem gatunków rozrywkowych, oferuje również warte uwagi powroty do korzeni współczesnej słowackiej kultury popularnej, a także interesujące rozważania o roli komiki i humoru.

\section{PhDr. Agnieszka Janiec-Nyitrai, PhD.}

Ústav slovanské a baltské filologie

Univerzita L. Eötvöse

Múzeum krt. 4/D., 1088 Budapešt', Mad’arsko

janiec.nyitrai@gmail.com 